Marta Justyna Nowicka

Uniwersytet Gdański

\title{
Miłość Fedry - obraz kazirodztwa jako namiętności zakazanej na podstawie wybranych reinterpretacji mitu
}

Kazirodztwo to relacja seksualna między osobami blisko spokrewnionymi, w której nie dochodzi do przymusu ani gwałtu. W większości społeczności, poza starożytnym Egiptem i Hawajami, kazirodztwo było zakazane, a także surowo karane. Zakaz to negatywna odwrotność reguły pozytywnej: obowiązku egzogamii. Akt jest napiętnowany przez opinię publiczną i zawsze przeżywany w tajemnicy, jako tragedia, która może prowadzić do szaleństwa, a nawet samobójstwa ${ }^{1}$. Na to kładzie się nacisk i tak rozłożone są akcenty we współczesnej, pochodzącej ze Stownika psychoanalizy, definicji incestu.

Historia incestu i próby jego definiowania są jednak tak stare jak ludzkość. Ludy najbardziej cywilizowane ograniczają się do zakazu stosunków między dziećmi i rodzicami, między braćmi i siostrami²; egzogamię francuski antropolog Claude Lévi-Strauss rozpatruje jako fundamentalny nakaz, przez który następuje przejście z Natury do Kultury. Tym, co przechodzi z Natury do Kultury, jest kobieta - egzogamię można bowiem interpretować jako rytuał wymiany. Kobiety są traktowane w nim jako przedmiot wymiany, stanowiący dar z energii ${ }^{3}$.

W starożytnej Grecji i w greckiej mitologii rytuały wymiany, a więc także związane $\mathrm{z}$ nimi płeć i życie płciowe, uważa się za niezbywalną cechę ludzkiej kondycji. Mit - od mitu o Pandorze - postrzega seksualność i płeć przede wszystkim w wymiarze

\footnotetext{
${ }^{1}$ Ch. Angot, Kazirodztwo, przeł. E. Wieleżyńska, Warszawa 2005, s. 113.

${ }^{2}$ G. Bataille, Historia erotyzmu, przeł. I. Kania, Kraków 1992, s. 24.

${ }^{3}$ Ibidem, s. 26-38.
} 
społecznym. Aseksualność i bezżeństwo to dla Greków podejrzane dziwactwa. Jednocześnie bóstwa greckie obowiązywały nieco odmienne normy i prawa - dziewicza Artemida to patronka noworodków oraz kobiet rodzących i w połogu, niezamężna i niechętna życiu seksualnemu. Demeter personifikowała macierzyństwo, a atrakcyjna seksualnie Hera uosabia małżeństwo, ale nie macierzyństwo ${ }^{4}$.

Arystotelesowska koncepcja mitu definiuje go jako samą fabułę, to, co zostanie z tragedii po usunięciu kształtu inscenizacyjnego, muzyki i wersyfikacyjnych cech wypowiedzi. Kazirodztwo jako temat fabuły pojawia się w zadziwiająco wielu mitologiach i innych tekstach kultury. Najpopularniejszy mit o inceście, czyli historia zakazanej miłości Fedry do Hipolita, to prawdopodobnie kontynuacja legendy trojdzeńskiej, popularnej w VII i VI w. p.n.e., i jeszcze wcześniejszej biblijnej przypowieści kanaanickiej, o miłości żony Putyfara do młodego Józefa (Księga Rodzaju, XXIX). W samej Grecji funkcjonowały także mit o Bellerofoncie i Fryksosie oraz opowieść o Tenesie i jego zakochanej w nim macosze Fylone ${ }^{5}$.

George Bataille zakłada, że o sile i zakazanym obiekcie nieustannie narastającego uczucia Fedry mogło zadecydować towarzyszące mu obrzydzenie - gdyby nie ono, pragnienie nie zaistniałoby $\mathrm{z}$ taką mocą, bo nie miałoby co go wzmagać ${ }^{6}$. Tragedia Fedry ujawnia przywiązanie do archaicznej kultury wstydu (aidos), w której najistotniejszym wyznacznikiem moralnej siły człowieka był respekt dla opinii ogółuㄱ, wiążący się w praktyce z kultem antyindywidualizmu.

${ }^{4}$ Zob. W. Lengauer, Męskie, żeńskie i nijakie. Sacrum płci w micie i wierzeniach Greków, „Collectanea Philologica”, t. II, Łódź 1995, s. 174-175.

${ }^{5}$ E. Wesołowska, Mit o Fedrze i Hippolicie - wciaż obecny w literaturze, „Balcanica Posnaniensia”, Poznań 1999, IX/X, s. 15-22.

${ }^{6}$ G. Bataille, op. cit., s. 81.

${ }^{7}$ M. Budzowska, Fedra czyli O etyce uczuć w tragediach Eurypidesa, Seneki i Racine'a, Warszawa 2010, s. 163. Cytowana przeze mnie pozycja jest najnowszą próbą porównania ze sobą Fedr, ale bez uwzględnienia późniejszych niż klasycystyczne interpretacji mitu, którymi zajmuję się w dalszej części tekstu. 
W patrylinearnej Grecji liczyło się tylko pochodzenie w linii męskiej i to syn stanowił kontynuację rodu męża. Autorzy tragedii poświęconych Fedrze podkreślają więc często, że jest ona córką Heliosa, a Hipolit - synem Tezeusza, nie wspominając o wojowniczej Antiope, matce Hipolita. Patrylinearność pokrywała się z patrylokalnością - miejsce rodziny było w grupie, z której wywodził się mąż, a kobiety postawione były w roli „obcych”/,zdobyczy”, wkraczających do rodu męża. „Obcość” kobiety nie wynikała tylko z jej obcej krwi, ale też z pochodzenia z odległej ziemi, jako że w pobliżu własnych ziem trudno było znaleźć niespokrewnioną kobietę. Bohaterki tragedii Eurypidesa reprezentujące model miłości zakazanej i potępianej, czyli Medea Kolchijka i Fedra Kretenka, stanowią przykłady kobiet „obcych”, które mogą stanowić zagrożenie dla rodów swoich mężów ${ }^{8}$. O swoim poczuciu wyalienowania Fedra Seneki mówi w następujący sposób: „w dom obcy nieprzyjazny za żonę wrogowi? Życie pędzę w łzach, w smutku. Męża w domu nie ma"'.

Do około 1950 r. p.n.e., kiedy agresywna inwazja plemion aryjskich spowodowała rozwój patriarchatu, społeczeństwo greckie było matryfokalne (dominował pozytywny symbol kobiecości). Wraz z początkami patriarchatu skupiono sie jednak na akcentowaniu niektórych brutalnych elementów religii matryfokalnej, takich jak składanie ofiar z ludzi. W ten sposób w świadomości społecznej zrodziły się Gorgona, Kirke, syreny i inne potwory płci żeńskiej ${ }^{10}$.

O potworach płci żeńskiej, kobietach dotkniętych emocjonalnym opętaniem, pisał outsider greckiego teatru Eurypides. Jego Fedra została pierwszy raz wystawiona w roku 428 p.n.e. w Atenach. Za drugą, zmienioną wersję dramatu Hippolitos zakrywajacy oblicze, nazwaną teraz Hippolitosem uwieńczonym, dramaturg

\footnotetext{
${ }^{8}$ M. Budzowska, op. cit., s. 143.

9 Seneka, Fedra, przeł. A. Świderkówna, Wrocław-Kraków 1959, w. 90-93.

${ }^{10}$ G. Baudler, Bóg i kobieta. Historia przemocy, seksualizmu i religii, przeł.
} A. Baniukiewicz, Gdynia 1995, s. 286. 
zdobył pierwszą nagrodę. Historia Fedry, żony Tezeusza opętanej miłością do jej pasierba Hipolita, fana polowań z psami i męskich sportów, przeciwnego składaniu hołdu Afrodycie i jakiejkolwiek kobiecie, została przez Eurypidesa przedstawiona z dużą wrażliwością. Zarówno jednak stworzona przez niego postać Medei, jak i Fedry, nie mogłaby przekonać ateńskiego widza do głoszonych przez siebie poglądów. Formułującym postulaty tragika Medei, barbarzynce-dzieciobójczyni, i pogrążonej w kazirodczej miłości Fedrze brakuje siły przekonywania dlatego, że są kobietami ${ }^{11}$.

Poglądy twórcy to jedna kwestia, a odczytanie i interpretacja mitu druga. W jednym z najpopularniejszych tłumaczeń Eurypidesowskiej Fedry autorstwa Bogusława Butrymowicza z 1928 roku twórca wstępu, Seweryn Hammer, w znacznie większym stopniu skupia swoją uwagę na postaci Hipolita niż Fedry. Zdaniem Hammera czystość czczonego w Trojdzenie jako boga Hipolita „bardziej jaśnieje w ogniu próby"12, jaką jest bycie obiektem niechcianego uczucia. Jego nienawiść do rodu niewieściego i abstynencję (hetero)seksualną autor wstępu sprzed prawie wieku rozumie jako dążenie do ideałów (a nie miłości przyziemnej, jakiej patronuje Afrodyta), za które warto poświęcić życie, by zyskać chwałę pośmiertną ${ }^{13}$. Przysposobiony syn Tezeusza interpretowany jest jako postać pozytywna i ambitna - ma w duszy „posiewy szlachetne”, nie skupia się na władzy, a na cnotach rycerskich. Ćwiczy i poluje, „obcy jest wszelkiej zniewieściałości”, co podkreśla Hammer we wstępie, dodając jednak, że jego nieuprzejmość wobec nieznanej mu płci, której zarzuca bezmyślność, lubieżność, gadatliwość i zdradę, „oziębia cokolwiek nasz stosunek do bohatera”" ${ }^{14}$.

Hipolit w tej wersji tragedii i tym opracowaniu przedstawiony jest przede wszystkim jako męczennik Artemidy; nie ma nacisku

11 M. Budzowska, op. cit., s. 94-95.

12 S. Hammer, Wstep, [w:] Eurypides, Hippolytos czyli Fedra, Kraków 1928, S. III.

13 Ibidem, s. XXII.

${ }^{14}$ Ibidem, s. XXIII-XXIV. 
na jego mizoginię, narcyzm i egocentryzm. Gdy zostaje wygnany przez Tezeusza z powodu fałszywego oskarżenia w liście zmarłej Fedry, rusza za nim gromada chłopców, z którymi ćwiczył, walczył i się wychowywał. O płci pięknej w pozytywny sposób nie wspomina ani razu w całej tragedii. Kiedy umierający Hipolit zostaje ponownie sprowadzony na dwór Tezeusza, by tam skonać, przedstawiony jest jako piękny męczennik - poeta zwraca uwagę na jego młodość, urodę i rany. Estetyka opisów konającego bohatera przypomina opisy umierającego Jezusa lub krwawiącego św. Sebastiana, notabene ikon kultury gejowskiej, mimo podkreślania niezniewieściałości Hipolitosa (złote włosy, zniewolone, poranione ciało i omdlewający od nadmiaru cierpienia wzrok). A przecież mizoginia to niemalże konstytutywna cecha Hipolita. Szczególnie wyraźnie akcentuje to tekst Seneki, gdzie syn Antiope ocenia płeć niewieścią następującymi słowami:

Lecz zła wodzem - kobieta. Ta mistrzyni zbrodni

Umie opętać duszę, przez jej to rozpustę

Zgliszcza tylu miast dymią (...)

Nie wspomnę tu o innych - dość jednej Medei,

By obrzydzić na zawsze całą płeć niewieścią ${ }^{15}$.

Nienawidzę, nie cierpię, brzydzę się, unikam

Wszystkich. Czy to rozsądek, instynkt czy szał groźny,

Wstręt ten mi się podoba ${ }^{16}$.

Postać Fedry w oczach Hipolita urasta do miana symbolu nieopanowania, antyideału, tym samym nosi znamiona archetypu. Reprezentuje przeklęty ród kobiet kreteńskich, które charakteryzują zbytnia emocjonalność i tendencja do wikłania się w haniebne związki.

Gwałtowna miłość każdej z Fedr opisywana jest z użyciem środków poetyckich charakterystycznych dla topiki lux tenebrae nieustannie kontrastowane są ze sobą jasność i ciemność.

15 Seneka, op. cit., w. 559-564.

${ }^{16}$ Ibidem, w. 566-568. 


\section{Pali serce moje płomień}

Namiętności obłędnej. Jej to szał głęboko

Aż gdzieś w szpiku wrze we mnie i żyłami płynie.

W wnętrznościach ogień skrywam i miłość tajemną

Jak pożar, co iskrami przebiega po dachu ${ }^{17}$.

Ze światłem i mrokiem można Fedrę wiązać zarówno metaforycznie, jak i dosłownie - u starożytnych jest ona córką Heliosa, boga słońca. Natomiast w religiach monoteistycznych bohaterka traci swą pozycję - jej bunt jest nie do zaakceptowania dla chrześcijańskiego Boga. Płomienna i ciemna miłość Fedry paradoksalnie sieje większe spustoszenie niż nienawiść: dezorganizuje jej życie, odczuwana jako hańba jest cierpieniem nie do zniesienia, niszczy ją samą, Hipolita, Tezeusza oraz dzieci. Ujęcie Eurypidesa pokazuje, że dramat Fedry ma charakter tak osobisty, jak społeczny. Niespełniona, wzgardzona miłość wiąże się z utratą szacunku i powoduje upadek społeczny królowej. To, co czuje, to zderzenie głęboko zakorzenionej obawy przed utratą czci i ogromnej potrzeby akceptacji ze strony wspólnoty z rodzącą się myślą o wolności własnych pragnień, nieprzystawalnych do norm społecznych ${ }^{18}$.

Kolejni twórcy nie zawsze jednak mieli dla Fedry tyle sympatii co Eurypides. Od czasów Liwiusza Andronikusa do Akcjusza Hippolita Eurypidesa z powodu wątku kazirodczej miłości nie przerabiał dla sceny rzymskiej żaden tragik. Epoka pryncypatu, gdy kazirodcze stosunki zdarzały się pośród tzw. wyższych sfer, stworzyła „klimat” dla recepcji tego rodzaju tematów w tragediach ${ }^{19}$. Ocena Seneki jest widoczna aż do ostatniego wersu utworu - tragedię rzymską kończą następujące słowa, jakimi Tezeusz żegna byłą małżonkę: „Niech ziemia będzie ciężka jej głowie bezecnej”20. Samobójstwo jest w sztuce Seneki wręcz gloryfikowane jako niezawodny środek wyjścia $\mathrm{z}$ dręczących sytuacji życiowych

\footnotetext{
17 Ibidem, w. 640-644.

${ }_{18}$ M. Budzowska, op. cit., s. 121.

19 W. Strzelecki, Wstęp, [w:] Seneka, Fedra, Wrocław-Kraków 1959, s. XLIV.

${ }^{20}$ Seneka, op. cit., w. 1280. Słowa Tezeusza nawiązują do „sit tibi terra levis”.
} 
(„O śmierci, złej miłości jedyny lekarzu,/O śmierci, czci zelżonej najlepszy obrońco" ${ }^{21}$ ); rzymski tragik ocenia postawę Fedry z punktu widzenia stoickiej koncepcji emocji, w której stany emocjonalne to zjawiska nienaturalne dla człowieka i niosące ze sobą cierpienie. Według stoików przyczyną ludzkich działań są najpierw naturalne instynkty, a później rozum i instynkty. Emocje traktuje się więc jako odchylenie umysłu, chorobę duszy ${ }^{22}$. Fedra Seneki nie walczy z namiętnością, ale próbuje znaleźć dla niej jakąś przestrzeń. „Zniża się" do próśb i błagań - przez co zmniejsza się szansa na sympatię ze strony czytelników.

Tragedia Seneki to popis retorycznego kunsztu; częstą postacią dyskusji między bohaterami jest controversia $\mathrm{w}$ formie agonu na temat kontrolowania namiętności. To już nie Eurypidejska delikatność w opisywaniu uczuć Fedry, mieszkanki płaczących pól Eneidy Wergiliusza, ale pejoratywnie oceniane psychopatologiczne stany. Seneka ustami Piastunki namawia Fedrę do stłumienia uczucia, co zdaniem stoików było możliwe dzięki sile woli.

Błagam cię, ugaś płomień miłości bezbożny! (...)

Zamierzasz ojca łoże połączyć i syna,

W łonie bezbożnym począc potomstwo podwójne?

Łam więc prawa natury przez występną żądzę,

Niech rodzą się potwory! (...)

Czyż zawsze świat o dziwach ma słyszeć niezwykłych,

Prawa natury milknąć, gdy tylko niewiasta

Kreteńska zechce kochać? ${ }^{23}$

${ }^{21}$ Ibidem, w. 1188-1189.

${ }^{22}$ Stoicy definiują stany emocjonalne jako pulsowanie (ptoia), skurcz i rozkurcz (systole i diachrysis), wznoszenie i upadek (eparsis i ptosis), depresję (tapeinosis) i zgryzotę (dexis). Emocje zdaniem stoików zawsze niosą za sobą cierpienie, chyba że emocja wynika z wrażenia zaakceptowanego przez umysł jako słuszne. Dlatego odmawiają dzieciom zdolności przeżyć emocjonalnych, sprowadzając ich zachowania do instynktownych działań samozachowawczych. Zob. G. Striker, Emotions in Context: Aristotle's Treatment of the Passion in the Rhetoric and his Moral Psychology, [w:] Essays on Aristotle's Rhetoric, red. A. Rorty, Berkeley-Los Angeles 1996, s. 286-299.

${ }^{23}$ Seneka, op. cit., w. 165-177. 
Z kolei Fedra Racine'a, wystawiona po raz pierwszy 1 stycznia 1677 jako piąta interpretacja mitu na gruncie francuskim, wywołała gwałtowną krytykę i była grana przy pustej sali, tymczasem tragedia jego literackiego przeciwnika, Pradona, w której autor, wbrew antycznej wersji mitu, uczynił Fedrę nie żoną, a narzeczoną Tezeusza, zyskała powszechne uznanie i długo nie schodziła ze sceny $^{24}$. Francuski twórca wprowadza do dramatu postać Arycji, w której kocha się Hipolit. Roland Barthes w Człowieku Racine'a twierdzi, że Racine usiłował „zdefeminizować” Hipolita, każąc mu kochać Arycję z obawy, by publiczność nie uznała go za zboczeńca ${ }^{25}$.

Ponadto Racine do swojej wersji tragedii wprowadza śmierć Tezeusza, przyczynę nowego, istotnego wątku o sukcesję władzy po zmarłym królu. Pretendentami do tronu w Atenach stają się Fedra i jej dziecko ze związku z Tezeuszem, Hipolit oraz Arycja, potomkini rodów pokonanych przez Tezeusza. Francuski autor podkreśla tym samym deprymujący fakt, że namiętności i emocje nie należą jedynie do sfery intymnej człowieka, ale też determinują zmiany zachodzące $\mathrm{w}$ polityce. Trójkąt miłosny przenika się $\mathrm{z}$ trójkątem władzy, a zazdrość czyni bohaterkę Rasynowską bardziej ludzką ${ }^{26}$, upodabnia ją też do Eurypidesowej Medei. Na pierwszy plan dramatu wysuwa się postać Arycji, która nie mówi o swoich uczuciach do Hipolita, a czuje satysfakcję z bycia przedmiotem jego uczucia. Jej miłość jest erotyczno-pragmatyczna (to szansa na odzyskanie wolności) i stanowi kontrast dla niemożliwej do spełnienia miłości Fedry, zatraconej w ogniu trawiącej ją namiętności. Racine skonstruował trójkąt miłosny, w którym Arycja i Fedra dominują nad Hipolitem i stanowią swoje symetryczne odbicie.

Opuszczona przez Boga, upokorzona, porzucona dla młodszej rywalki przez ukochanego, postanawia - jak wszystkie jej

${ }^{24}$ T. Żeleński (Boy), Wstęp, [w:] J. Racine, Fedra, przeł. T. Żeleński (Boy), Warszawa [ca 1930], s. LXVI.

${ }^{25}$ R. Barthes, Człowiek Racine'a, [w:] idem, Mit i znak. Eseje, przeł. W. Błońska, J. Błoński, J. Lalewicz, A. Tatarkiewicz, Warszawa 1970, s. 105.

${ }^{26}$ M. Budzowska, op. cit., s. 267. 
poprzedniczki - popełnić samobójstwo. Każda z Fedr wybrała jednak inny sposób i miała inną motywację dla zakończenia życia. Grecka spuszcza sznur z powały ślubnej komnaty, rzymska przebija się mieczem, francuska zażywa truciznę o przedłużonym działaniu. Podobny los spotyka ją w awangardowych inscenizacjach dokonanych przez współczesnych twórców, pokazujących aktualność mitu opowiadającego o nieszczęśliwie zakochanej kobiecie: Fedra Enquista ginie, wbiwszy sobie po cichu nóż w brzuch, potem zabiera ją Czyściciel; Fedra Kane wiesza się, a stos z jej ciałem podpala Tezeusz. Każda $\mathrm{z}$ nich ginie $\mathrm{w}$ poczuciu porażki i poniżenia, każda mierzy się z uczuciem w samotności, mając do dyspozycji tylko jedną przychylną duszę, wspólniczkę. We wszystkich sztukach poza Miłościa Fedry Kane jest to piastunka reprezentująca relatywizm norm moralnych, modyfikowalnych jej zdaniem w obronie wartości najwyższej - ludzkiego życia. Eurypidesowska Fedra na próbę usprawiedliwienia swojej sytuacji przez Piastunkę reaguje gniewem i odrzuceniem obrzydliwego dla niej relatywizmu moralnego, Fedra Seneki natomiast sama formułuje pełne nadziei przypuszczenia co do możliwości usankcjonowania jej związku z Hipolitem. U Racine’a po śmierci Tezeusza bohaterki nie wini się za pogwałcenie więzów małżeństwa - Fedra daje się przekonać Enonie, że relacja między pasierbem a macochą nie jest formą incestu. Im bliższa współczesności sztuka, tym mniejszy nacisk kładzie się na winę, a większy na przemożność uczucia, którego siły współczuje Fedrze Oinone tak dzieje się u Pera Olova Enquista, a u Sarah Kane obsesji Fedry świadomi są wszyscy, sam Hipolit zaleca jej „leczniczy” romans.

U szwedzkiego dramaturga, autora Dla Fedry, dialogi postaci przypominają taniec bokserów na ringu. Enquist podkreśla też niezdolność Hipolita do objęcia przez niego tradycyjnej męskiej roli wojownika, podejmowanej przedtem przez jego ojca, dzielnego Tezeusza, a także matkę, Amazonkę Antiope. Jako „bohaterskie czyny”, do których powołany miałby być Hipolit, jego wychowawca rozumie również gwałty i innego rodzaju zbrodnie wojenne 
(bohaterowie „mają czyste miecze lecz członki brudne”27). Theramenes $\mathrm{w}$ tej reinterpretacji mitu wyznaje miłość swojemu podopiecznemu, na co młody, wyraźnie zirytowany Hipolit odpowiada: „Kocham, kocham, kocham. Już dłużej nie mogę tego słuchać! Gdy miłość przechodzi przez pokój zostawia po sobie trupi zapach!”28. Aseksualny, wyznający bez przekonania miłość Arycji, nieczujący i niepragnący Hipolit Enquista bliskość rozumie jako coś odrzucającego i zbędnego.

U Enquista, zgodnie z tradycją interpretacji mitu Fedry, jej uczucie zostaje porównane do ognia. „To cię spali Fedro!”29 - mówi Oinone, służka. Spala również słońce, karząc niewierne żony, związywane w południe pośrodku rynku, a następnie pokrywane aż do śmierci przez niewolników

Fedra zdaje się jednocześnie przerażona i zafascynowana możliwością bycia ukaraną za incest. Fascynuje ją śmierć jako doświadczenie wyrywające z tego, w czym wbrew swej woli trwa, jak Kane'owski Hipolit, który w ostatnim zdaniu dramatu brytyjskiej brutalistki, umierając od ciosów tłumu i widząc gromadzące się nad nim sępy, mówi: „Gdyby takich chwil było więcej”30. Fedra z kolei zwraca się do Oinone: „Otwórz okiennice, a słońce zrobi swoje. Spali... (Odchyla mocno głowę do tyłu, na ustach prawie uśmiech, prawie radość (...) Wszystko)!”’31. Ginący bohaterowie swoim stoickim podejściem do śmierci potwierdzają istnienie Hebblowskich bohaterów prawdziwie tragicznych, którzy los swój przyjmują ze spokojem, a śmierć traktują jako szansę na odkrycie w genialnym przebłysku faktycznych związków łączących to, co indywidualne, z tym, co ogólne ${ }^{32}$. Jedynie w tekście Kane Hipolit jest w miarę

${ }^{27}$ P.E. Enquist, Dla Fedry; Z życia glist; Godzina kota; Tupilak, przeł. A. Krajewski-Bola, Izabelin 1997, s. 16.

${ }^{28}$ Ibidem, s. 15.

${ }^{29}$ Ibidem, s. 20.

${ }^{30}$ S. Kane, Miłość Fedry, przeł. M. Semil, „Dialog” 1999, nr 9, s. 75.

${ }^{31}$ P.E. Enquist, op. cit., s. 59.

32 Por. M. Carlson, La tradizione tedesca nel tardo ottocento, [w:] Teorie del teatro, przeł. L. Galdini, il Mulino, Bolonia 1997, s. 280-281. 
sympatyczną postacią pierwszoplanową, a nie wyłącznie nadętym mizoginem; jedynie w jej tekście dochodzi też do jakiegokolwiek zbliżenia pomiędzy pasierbem a macochą.

To, co zakazane, sięga po Fedrę, która zwierza się „wstrętnej wysuszonej rodzynce"33, czyli staruszce, jedynej osobie, jakiej ufa opowiada o początkach swojego uczucia, jego sile, o seksie z Tezeuszem, którego już nie pożąda ${ }^{34}$. Swoje pragnienie wypowiedzenia miłości niewypowiedzianej, której urzeczywistnienie jest zabronione przez religię i społeczeństwo, szwedzka i współczesna Fedra opisuje tak:

Chciałabym go chwycić w moje ręce uwięzić sen.

Odciąć go nożem, by stał się rzeczywisty.

Ciąć jego mięso tak, by każdego plastra można było dotknąć.

Mięso, którego można dotknąćc $c^{35}$.

Opis ten przypomina dramatyzacje Krzysztofa Warlikowskiego sztuk Sarah Kane, podkreślające dosłowność metafor i intensywność emocjonalną tekstów angielskiej autorki. Zamiast prologu czy parodosu, wprowadzających w zawiłości akcji, Kane w pierwszej scenie dramatu dosadnie opisuje masturbującego się i jednocześnie jedzącego hamburgera podczas oglądania brutalnego filmu Hipolita, któremu nic nie sprawia radości.

Targające bohaterami emocje od wieków przedstawiano w wyrazistych monologach, pełnych metafor, wykrzyknień itd. Techniki charakterystyczne dla tekstów tworzonych w wieku XX i XXI pozwalają na ukazanie tych stanów w nowy sposób, na przykład za pomocą strumienia świadomości ${ }^{36}$ lub w sposób typowy dla Kane przez serię bezpośrednio następujących po sobie, wykluczających

${ }^{33}$ P.E. Enquist, op. cit., s. 23.

${ }^{34}$ Ibidem, s. 27.

35 Ibidem, s. 28.

${ }^{36}$ Technik tych z powodzeniem używali nie tylko James Joyce i Virginia Woolf, ale też Samuel Beckett czy na rodzimym gruncie Witold Gombrowicz. 
się wzajemnie nakazów i zakazów, kierowanych do bliskiej podmiotowi mówiącemu osoby. W trzeciej scenie dramatu Fedra mówi do swojej córki, Strofy (postaci dodanej do reinterpretacji mitu przez Kane): „Won odwal się nie dotykaj mnie nie odzywaj się do mnie zostań ze mną" ${ }^{37}$. Jest to język sprzecznych potrzeb, doskonale charakteryzujący pałającą niedozwoloną namiętnością Fedrę. Tylko w dramacie Kane Fedra zaprzecza uczuciu i pożądaniu, które dostrzegają u niej najpierw lekarz Hipolita, a potem własna córka. $\mathrm{W}$ przeciwieństwie do poprzednich wariacji na temat tragedii Eurypidesa to Hipolit, a nie tytułowa „miłość Fedry”, jest zarzewiem ognia rozprzestrzeniającego się na jego bliskich, szczególnie tych, którzy mieli z nim kontakt seksualny. Nie tylko Fedra, ale i Strofa, przyrodnia siostra Hipolita, czuje, że płonie.

Nie mogę tego w sobie zgasić. Nie mogę tego zdusić. Nie mogę się z tym budzić, z tym płomieniem. (...)

Wiem, kiedy się kocha, naprawdę kocha... (...)

kocha tak, że aż się płonie ${ }^{38}$.

Hipolit jednak tradycyjnie odrzuca zaloty macochy, zarówno te werbalne, jak i oralne ${ }^{39}$. W dramacie brutalistki pasierb zaraża Fedrę rzeżączką (albo mówi jej, że to zrobił, by zaczęła go nienawidzić, zamiast kochać), a ona, aby tradycji mitycznej stało się zadość, składa na niego donos. Hipolit jednak bardzo różni się od swoich poprzedników - na słowa Strofy: „Moja matka oskarża cię o gwałt”, odpowiada: „Naprawdę? To ciekawe” ${ }^{40}$. Dobrowolnie oddaje się $w$ ręce sprawiedliwości. Tezeusz sam podpala stos, na którym ostatecznie spłonie Fedra. W najbardziej współczesnej rewizji

${ }^{37}$ S. Kane, op. cit., s. 59.

${ }^{38}$ Ibidem, s. 60.

39 Po wykonanym przez Fedrę fellatio, Hipolit wykazuje się w przeciwieństwie do swoich poprzedników jakąś ludzką reakcją, wchodzi w dialog z macochą, mówiąc: „Nienawidzisz tego tak samo jak ja, tylko nie chcesz się przyznać” (ibidem, s. 65).

40 Ibidem, s. 67. 
mitu o kazirodczym pożądaniu i jego sile żaden z głównych bohaterów nie pozostaje przy życiu.

Incest w dalszym ciągu jest częstym tematem sztuki współczesnej. Jednak postrzegany bywa zupełnie inaczej niż kiedyś - pisarki takie jak Anaïs Nin czy Christine Angot, opisując swoje doświadczenia z kazirodztwem, łamią tabu, uważając je za akt inicjacyjny, niezbędny dla ich dalszego rozwoju i kariery. Stosunek z własnym ojcem jest dla nich przedmiotem opisu literackiego. Sceniczne dzieje Fedry dowodzą, że Eurypides okazał się twórcą o wiele bardziej wrażliwym na tragedię nieszczęśliwie zakochanej kobiety niż pobożny Racine, a tym bardziej przeraźliwie moralizatorski Seneka. Podobną wrażliwość można spotkać dopiero u twórców współczesnych, zwracających większą uwagę od poprzedników na postać stroniącego od miłosnych uniesień młodzieńca. U Enquista Fedra zdaje się zafascynowana możliwością zagłady, podobnie jak odstręczający swoją nieudolnością i kompleksami Hipolit. Jedynie Kane przedstawia młodzieńca w bardziej przewrotny sposób, upodobniając go do mitycznej Fedry.

\section{Bibliografia}

Angot Ch., Kazirodztwo, przeł. E. Wieleżyńska, Warszawa 2005.

Barthes R., Mit i znak. Eseje, przeł. W. Błońska, J. Błoński, J. Lalewicz, A. Tatarkirwicz, Warszawa 1970.

Bataille G., Historia erotyzmu, przeł. I. Kania, Kraków 1992.

Baudler G., Bóg i kobieta. Historia przemocy, seksualizmu i religii, przeł. A. Baniukiewicz, Gdynia 1995.

Budzowska M., Fedra czyli o etyce uczuć w tragediach Eurypidesa, Seneki i Racine'a, Warszawa 2010.

Carlson M., Teorie del teatro, przeł. L. Galdini, Bolonia 1997.

Enquist P.E., Dla Fedry; Z życia glist; Godzina kota; Tupilak, przeł. A. Krajewski-Bola, Izabelin 1997.

Eurypides, Hippolytos czyli Fedra, przeł. B. Butrymowicz, Kraków 1928.

Kane S., Miłość Fedry, przeł. M. Semil, „Dialog” 1999, nr 9.

Lengauer W., Męskie, żeńskie i nijakie. Sacrum płci w micie i wierzeniach Greków, „Collectanea Philologica”, t. II, Łódź 1995. 
Racine J., Fedra, przeł. T. Żeleński (Boy), Warszawa [ca 1930].

Seneka, Fedra, przeł. A. Świderkówna, Wrocław-Kraków 1959.

Wesołowska E., Mit o Fedrze i Hippolicie - wciąz obecny w literaturze, „Balcanica Posnaniensia”, Poznań 1999, IX/X. 